\title{
IMPACT OF MULTIPLE-ENZYME MIXTURE ON PERFORMANCE OF BROILERS FED CORN-SOYBEAN MEAL DIETS
}

\author{
A.I. El-Faham; Nematallah G.M. Ali and M.A.M. Abdelaziz \\ Poultry Science Department, Ain Shams University, Cairo 11241, Egypt.
}

\section{SUMMARY}

\begin{abstract}
$\mathrm{T}$ his study aimed to investigate effects of supplementing corn-soybean meal diets of broilers with enzyme mixture (Phytabex plus ) on growth performance, slaughter traits and blood metabolites. A total of 150 one day old Avian broiler chicks (sex-mixed) were subjected to a 5 weeks dietary experiment. Chicks were randomly divided into 5 experimental groups [basal diets supplemented with 0,100 , 150, 200 and $200 \mathrm{~g} /$ ton Phytabex plus, during starter (0-3 weeks) and 0, 100, 150, 200 and $100 \mathrm{~g} /$ ton Phytabex plus, during grower (4-5 weeks)]. Each treatment comprised 3 replicates (10 chicks per replicate). Results indicated that, chicks fed diet supplemented with $100 \mathrm{~g} /$ ton Phytabex plus (T2) had significantly heavier live body weight (LBW) by (4.11 (T1), 9.39 (T3), 4.98 (T4) and 4.83\% (T5) than other treatments. Feed conversion ratio (FCR) was 1.86, 1.95, 1.99, 1.90 and 1.95 for birds fed diet supplemented with different levels of Phytabex plus (T1: T5) respectively. In addition, birds fed diet supplemented with $150 \mathrm{~g} /$ ton Phytabex plus (T3) recorded higher dressing percentage and ready to cook at 5 weeks of age compared to other groups. Moreover, enzyme supplementation significantly increased plasma total protein and globulin while, total cholesterol and alanine transaminase (ALT) were insignificantly affected by dietary treatments. Economic traits during the trial period were decreased for chicks fed any of experimental diets as compared with those fed the control diet. It is clear from the present study that using Phytabex plus at $100 \mathrm{~g} /$ ton improved LBW and at $150 \mathrm{~g} /$ ton improved percentage of dressed weight and total edible parts and there was no negative effect on liver but favorable effects were noticed on some blood parameters, while there was no economical benefit upon using Phytabex plus .
\end{abstract}

Keywords: corn-soybean meal, enzyme mixture and broiler performance

\section{INTRODUCTION}

Feeding enzymes to poultry is one of the major nutrition advances in the last fifty years. The main potential of enzyme addition to feed appears for digestion of substances that an animal is intrinsically incapable of digesting (Cheeke, 1991). These enzymes can open up to the complex feed cell walls, allowing the animals own enzymes to digest the enclosed nutrients. These complexes are only a fraction of the polysaccharides present in the digesta and are made up of a number of different components. (Austin et al., 1999). High digesta viscosity can lead to reduced feed intake, slower digesta passage rate and impaired nutrient digestion (Naqvi and Nadeem, 2004). It is well known that exogenous enzymes have been shown to improve performance and nutrient digestibility when added to poultry diets containing cereals, such as barley (El-Faham and Ibrahim, 2003); wheat (Kalmendal and Tauson, 2012), and to those containing rye (Lázaro et al., 2003). However, it has been reported also that multi-enzyme products improve bird's productivity (El-Faham and Ibrahim, 2004) and digestibility of corn and soybean meal, which induce less viscosity of digesta for broilers (Olukosi et al., 2007). The impact of many commercial enzyme products have been well stated, but there is still some vagueness in their mode of action (Bedford, 2002). Moreover, several reports indicated that using an enzyme cocktail (Zado), has beneficial effects on broiler productivity when birds fed a corn-soybean meal (SBM) based diet, which are reflected on economic benefits for producers. (Safaa, 2013). Also, Kocher et al. (2003) reported that using an enzyme cocktail containing pectinase, amylase and protease in corn-SBM-based diets for chicks resulted in improved performance. In addition, Kalmendal and Tauson (2012) observed that the combination of xylanase and serine protease improved FCR, compared with the control diet but, LBW and feed intake were not affected by enzyme addition. Moreover, Gracia et al., (2003) demonstrated that amylase was a critical enzyme to improve the nutritional value of corn-based broiler diets, improving body weight gain (BWG) and FCR by 4 to $9 \%$ compared with an un-supplemented control diet. On the other hand, Barekatain et al. (2013) observed that the addition of xylanase and protease to broiler cornSBM based diets up to 21 days of age did not result in further improvement in productive performance 
represented by body weight gain, feed intake and FCR. Moreover, Kocher et al. (2002) reported that addition of enzymes' complex from 4 to 38 days of age had no effect on BWG or FCR of broilers fed on a corn-SBM diet.

Therefore, the aim of this study was to evaluate the impact of commercial enzymes' complex (Phytabex plus ) supplementation to broiler fed corn-SBM based diets on productive performance, carcass characteristics and blood metabolites.

\section{MATERIALS AND METHODS}

This study was conducted at Poultry Experimental Unit, Agricultural Experiment and Research Station at Shalakan, Faculty of Agriculture, Ain Shams University, Egypt.

\section{Birds and Diets}

A total of 150 Avian broiler chicks (mixed sex) at one-day old with an initial body weight ranged between 44.0 and $47.0 \mathrm{~g}$ were obtained from a local commercial hatchery. Chicks were then divided randomly into 5 treatments [basal diet supplemented with Phytabex plus at (0, 100, 150, 200 and $200 \mathrm{~g} /$ ton in starter basal diet) and $(0,100,150,200$ and $100 \mathrm{~g} /$ ton in grower basal diets)]. The chicks were weighed individually and randomly allocated to 5 dietary treatments groups, each group contained 30 chicks which were allotted into 3 replicates, and each replicate contained 10 chicks. Basal starter (0-3 wks) and grower (4-5 wks) diets were formulated according to the nutritional recommendation of NRC (1994) for broilers, their composition and calculated analysis are shown in Table (1). Phytabex plus is a

Table (1): Feed ingredients and chemical composition of basal diets:

\begin{tabular}{lcc}
\hline \multirow{2}{*}{ Ingredients } & \multicolumn{2}{c}{ Dietary Treatments } \\
\cline { 2 - 3 } Corn (grains) & Starter $(0-3$ Weeks $)$ & Grower (4-5 Weeks) \\
Soybean meal (44\%) & 54.50 & 57.50 \\
Corn gluten meal (62\%) & 33.00 & 28.00 \\
Soybean oil & 6.20 & 6.20 \\
Mono-calcium phosphate & 2.00 & 4.00 \\
Calcium carbonate & 1.80 & 1.80 \\
Premix & 1.60 & 1.60 \\
Salt (NaCl) & 0.30 & 0.30 \\
Methionine HA & 0.20 & 0.20 \\
HCL Lysine & 0.20 & 0.20 \\
Total & 0.20 & 0.20 \\
Chemical composition & 100 & 100 \\
Crude protein \% & & \\
ME Kcal/ Kg diet & 23.00 & 21.05 \\
Ca\% & 2986 & 3168 \\
AP\% & 1.02 & 1.00 \\
Lysine \% & 0.50 & 0.49 \\
Methionine + Cystein \% & 1.29 & 1.16 \\
Price/ Ton (L.E.) & 0.95 & 0.90 \\
Composition of & 3827 & 3808 \\
\hline
\end{tabular}

Composition of commercial multi enzymes (Phytabex Plus ): Each $1 \mathrm{Kg}$ contains

$\begin{array}{lll}\text { Xylanase } 10000000 \mathrm{IU} & \alpha \text {-Amylase } 100000 & \text { Cellulase 500000 IU } \\ \text { Acid Protease 2000000 IU } & \beta \text {-Glucanase 500000 IU } & \text { Food-grade corn starch carrier up } \\ \text { Phytase 5500000 IU } & \beta \text {-Mannanase } 800000 \mathrm{IU} & \text { to } 1 \mathrm{Kg}\end{array}$

Methionine HA: Methionine Hydroxy-Analogue, ME: metabolizable energy, AP: Available phosphorus.

Each $3 \mathrm{Kg}$ of the premix contains: Vitamins: A: $12000000 \mathrm{IU}$; Vit. D3 $2000000 \mathrm{IU}$; E: $10000 \mathrm{mg}$; K3: $2000 \mathrm{mg}$; B1:1000 mg; B2: $5000 \mathrm{mg}$; B6:1500 mg; B12: $10 \mathrm{mg}$; Biotin: $50 \mathrm{mg}$; Coline chloride: $250000 \mathrm{mg}$; Pantothenic acid: $10000 \mathrm{mg}$; Nicotinic acid: $30000 \mathrm{mg}$; Folic acid: $1000 \mathrm{mg}$; Minerals: Mn: $60000 \mathrm{mg}$; Zn: $50000 \mathrm{mg}$; Fe: $30000 \mathrm{mg}$; $\mathrm{Cu}: 10000 \mathrm{mg}$;: $1000 \mathrm{mg}$; Se: $100 \mathrm{mg}$ and Co: $100 \mathrm{mg}$.

dry stabilized preparation manufactured by ENBio-Tech Co., LTD, China, it is a multi-enzyme preparation, each $1 \mathrm{Kg}$ contains (Xylanase, Cellulase, B-Glucanase, B-Mannanase, Phytase, Acid protease, $\alpha$-Amylase and corn starch food grade (carrier) (Table, 1). Chicks in all treatments were reared 
under similar hygienic and managerial conditions. They were housed in well ventilated brooding pens from one-day up to $5 \mathrm{wks}$ of age, wheat straw was used as a litter, and feed and water were provided adlibitum throughout the experimental period.

\section{Parameters Measured}

Live body weight (LBW) and feed consumption (FC) for each replicate for all treatments were recorded, then were averaged and expressed in grams per chick throughout the experimental periods. Body weight gain (BWG) and feed conversion ratio (FCR) were also calculated during the same periods. Production Index (PI) was calculated according to North (1981).

At the end of 5 wks of age, three chicks from each treatment were randomly taken for slaughter. The birds were then immediately eviscerated by removing of head, feathers, lungs, feet and gastro-intestinal tract. The carcass parameters including weights of abdominal fat, liver, gizzard and heart were recorded. These weights were expressed in terms of percentage of live weight.

During slaughter, individual blood samples were taken from birds within each treatment and collected into dry clean centrifuge tubes containing drops of heparin and centrifuged for $15 \mathrm{~min}(3000 \mathrm{rpm})$ to obtain plasma. Plasma samples were stored at $-20^{\circ} \mathrm{C}$ in a deep freezer until the time of chemical determination. Quantitative determination of blood included the following: Total protein (according to Gornall et al., 1949), albumin (method as described by Doumas et al., 1971), globulin (determined by subtraction particular value of albumin from corresponding value of total protein), total cholesterol (enzymatic colorimetric method described by Richmond, 1973), aspartate aminotransferase (AST) and alanine aminotransferase (ALT) were determined according to the method of Reitman and Frankel (1957). All biochemical parameters of blood were calorimetrically diagnosing kits (produced by BioDiagnostics Company, Egypt).

Feeding economic efficiency was carried out according to the prices of feed ingredients, enzyme preparation and LBW during experimental time. A production cost analysis and economic evaluation was carried out according to methods described by North (1981) and Emmert (2000).

\section{Statistical Analysis}

Statistical analysis was conducted using the General Linear Model (GLM) procedure of SAS (2004). Means were compared using Duncan's Multiple Range Test (Duncan, 1955) where the level of significance was set at minimum $(\mathrm{P} \leq 0.05)$.

The statistical model was:

$\mathrm{Yij}=\mu+\mathrm{Ti}+\mathrm{eij}$

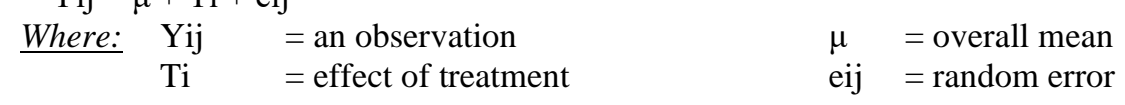

\section{RESULTS AND DISCUSSION}

\section{Growth performance}

Results of Table (2) showed that live body weight (LBW) was significantly affected due to enzyme supplementation during starter and grower stages. Bird's LBW was significantly increased by $7.12 \%$ for chicks fed (T2) diet than those fed the control (T1) diet at 3 wks of age, whereas was insignificantly increased by $4.29 \%$ at 5 wks of age. On the other hand, chicks fed (T2) diet had heavier LBW by 9.39, 4.98 and $4.83 \%$ than those fed (T3), (T4) or (T5) diet respectively at 5 wks of age. Daily weight gain (DWG) showed the same trend since chicks fed (T2) diet during all stages (0-3, 4-5 and 0-5 wks) reflected significantly the highest DWG compared with other treatments. However, during starter period (0-3 wks), chicks gained (33.15 vs. 30.81 g.), while during grower period (4-5 wks), chick gained (55.97 vs. $55.01 \mathrm{~g}$.) and during whole experimental period (0-5 wks) chicks gained (42.28 vs. $40.49 \mathrm{~g}$ ) compared with the control group (T1). Moreover, feeding (T2) diet gave higher DWG compared to (T3), (T4) or (T5) diets being 38.19, 40.11 and $40.18 \mathrm{~g}$, respectively, however, these differences failed to be significant. Similar observations were reported by other investigators, Shirmohammad and Mehri (2011) who reported that addition of enzyme preparation to broiler diet improved BWG significantly. Also, Osman et al. (2007) and Pourreza et al. (2007) reported that broiler chicks fed diets supplemented with enzymatic growth promoters (Ronozyme) achieved the highest LBW and BWG at 6 wks. In addition, Greenwood et al. (2002) showed that using a mixture of xylanase, protease and amylase enzymes with corn-soybean broiler starter diet improved LBW at 14 and 42 days of age. Data in Table (2) indicated that 


\section{El-Faham et al.}

daily feed consumption (DFC) per chick (g/ day) was significantly increased by feeding (T2) diet compared with those fed control (T1) diet and other dietary treatments (T3, T4 or T5). Increment of feed consumption was more pronounced during the grower period (4-5 wks) being $11.59 \%$, while it was only 6.93\% during the starter period (0-3 wks). Increased DFC (g/ d) could be related to the fact that broiler chicks consume more feed to meet energy requirements moreover broiler chicks require more dietary energy to maximize growth during short rearing periods (Al-Homidan, 2003). These results are in agreement with findings of Khan et al. (2006) and Pourreza et al. (2007) who concluded that dietary enzyme supplementation increased feed intake. In contrast, Zakaria et al. (2010) showed that enzyme supplementation had no significant effect on feed intake of birds. Feed conversion ratio (FCR) showed that, chicks fed control (T1) diet were more efficient in converting their feed into gain compared with those fed other (T2: T5) diets, and differences were significant except for (T4) diet. The best FCR was detected for chicks fed the control (T1) diet (1.86) or (T4) diet (1.90). On the other hand, the worst FCR were found in chicks fed (T3) diet (1.99), which could be due to the lowest DWG. These finding are in contrast with those obtained by Youssef et al. (2011) and Onu et al. (2011) who found that enzyme supplementation improved FCR of broilers. Similarly, Hassanein (2011) reported that FCR was significantly improved by supplementing enzyme preparation to bird's diet.

Table (2): Effect of different dietary treatments on productive performance.

\begin{tabular}{|c|c|c|c|c|c|c|}
\hline \multirow{2}{*}{ Item } & \multicolumn{6}{|c|}{ Dietary Treatments } \\
\hline & 1 & 2 & 3 & 4 & 5 & Sig. \\
\hline \multicolumn{7}{|c|}{ Live body weight (g) } \\
\hline 3 weeks & $\begin{array}{c}690.83^{\mathrm{b}} \\
\pm 1.82\end{array}$ & $\begin{array}{l}740.00^{\mathrm{a}} \\
\pm 21.93\end{array}$ & $\begin{array}{c}720.07^{\mathrm{ab}} \\
\pm 0.92\end{array}$ & $\begin{array}{c}736.03^{\mathrm{a}} \\
\pm 1.90\end{array}$ & $\begin{array}{c}742.33^{\mathrm{a}} \\
\pm 8.85\end{array}$ & * \\
\hline 5 weeks & $\begin{array}{c}1461.00^{\mathrm{ab}} \\
\pm 8.08\end{array}$ & $\begin{array}{c}1523.63^{\mathrm{a}} \\
\pm 13.06\end{array}$ & $\begin{array}{c}1380.50^{\mathrm{b}} \\
\pm 12.41\end{array}$ & $\begin{array}{c}1447.78^{\mathrm{ab}} \\
\pm 35.95\end{array}$ & $\begin{array}{c}1450.00^{\mathrm{ab}} \\
\pm 49.07\end{array}$ & * \\
\hline \multicolumn{7}{|c|}{ Daily weight gain (g) } \\
\hline $0-3$ weeks & $\begin{array}{l}30.81^{\mathrm{b}} \\
\pm 0.08\end{array}$ & $\begin{array}{l}33.15^{\mathrm{a}} \\
\pm 1.04\end{array}$ & $\begin{array}{c}32.20^{\mathrm{ab}} \\
\pm 0.04\end{array}$ & $\begin{array}{l}32.96^{\mathrm{a}} \\
\pm 0.08\end{array}$ & $\begin{array}{l}33.26^{\mathrm{a}} \\
\pm 0.42\end{array}$ & $*$ \\
\hline 4-5 weeks & $\begin{array}{l}55.01^{\mathrm{a}} \\
\pm 0.44\end{array}$ & $\begin{array}{l}55.97^{\mathrm{a}} \\
\pm 0.63\end{array}$ & $\begin{array}{l}47.17^{\mathrm{b}} \\
\pm 0.82\end{array}$ & $\begin{array}{c}50.84^{\mathrm{ab}} \\
\pm 2.43\end{array}$ & $\begin{array}{c}50.54^{\mathrm{ab}} \\
\pm 2.87\end{array}$ & * \\
\hline $0-5$ weeks & $\begin{array}{c}40.49^{\mathrm{ab}} \\
\pm 0.23\end{array}$ & $\begin{array}{l}42.28^{\mathrm{a}} \\
\pm 0.37\end{array}$ & $\begin{array}{l}38.19^{\mathrm{b}} \\
\pm 0.35\end{array}$ & $\begin{array}{c}40.11^{\mathrm{ab}} \\
\pm 1.02\end{array}$ & $\begin{array}{c}40.18^{\mathrm{ab}} \\
\pm 1.40\end{array}$ & $*$ \\
\hline \multicolumn{7}{|c|}{ Daily feed consumption $(\mathrm{g})$} \\
\hline 0-3 weeks & $\begin{array}{l}50.40^{\mathrm{c}} \\
\pm 0.05\end{array}$ & $\begin{array}{c}53.89^{\mathrm{ab}} \pm 0.9 \\
1\end{array}$ & $\begin{array}{l}53.08^{\mathrm{b}} \\
\pm 0.22\end{array}$ & $\begin{array}{l}52.61^{\mathrm{b}} \\
\pm 0.24\end{array}$ & $\begin{array}{l}54.77^{\mathrm{a}} \\
\pm 0.25\end{array}$ & $* *$ \\
\hline 4-5 weeks & $\begin{array}{c}112.75^{\mathrm{b}} \\
\pm 1.96\end{array}$ & $\begin{array}{c}125.82^{\mathrm{a}} \pm 2.7 \\
3\end{array}$ & $\begin{array}{c}110.55^{\mathrm{b}} \\
\pm 2.69\end{array}$ & $\begin{array}{c}111.67^{\mathrm{b}} \\
\pm 4.38\end{array}$ & $\begin{array}{c}113.94^{\mathrm{b}} \\
\pm 1.66\end{array}$ & $*$ \\
\hline $0-5$ weeks & $\begin{array}{l}75.34^{\mathrm{b}} \\
\pm 0.75\end{array}$ & $82.66^{\mathrm{a}} \pm 1.64$ & $\begin{array}{l}76.07^{\mathrm{b}} \\
\pm 1.21\end{array}$ & $\begin{array}{l}76.23^{b} \\
\pm 1.61\end{array}$ & $\begin{array}{l}78.44^{b} \\
\pm 0.81\end{array}$ & $* *$ \\
\hline \multicolumn{7}{|c|}{ Feed conversion ratio ( $\mathrm{g}$ feed/ $\mathrm{g}$ gain) } \\
\hline $0-3$ weeks & $\begin{array}{l}1.63^{\mathrm{ab}} \\
\pm 0.01\end{array}$ & $\begin{array}{l}1.63^{\mathrm{ab}} \\
\pm 0.02\end{array}$ & $\begin{array}{l}1.65^{\mathrm{a}} \\
\pm 0.01\end{array}$ & $\begin{array}{l}1.60^{\mathrm{b}} \\
\pm 0.01\end{array}$ & $\begin{array}{l}1.64^{\mathrm{ab}} \\
\pm 0.01\end{array}$ & $*$ \\
\hline $4-5$ weeks & $\begin{array}{l}2.02^{\mathrm{b}} \\
\pm 0.05\end{array}$ & $\begin{array}{l}2.25^{\mathrm{a}} \\
\pm 0.07\end{array}$ & $\begin{array}{l}2.34^{\mathrm{a}} \\
\pm 0.01\end{array}$ & $\begin{array}{l}2.20^{\mathrm{ab}} \\
\pm 0.01\end{array}$ & $\begin{array}{l}2.26^{\mathrm{a}} \\
\pm 0.09\end{array}$ & $*$ \\
\hline $0-5$ weeks & $\begin{array}{l}1.86^{\mathrm{c}} \\
\pm 0.01\end{array}$ & $\begin{array}{l}1.95^{\mathrm{ab}} \\
\pm 0.02\end{array}$ & $\begin{array}{l}1.99^{\mathrm{a}} \\
\pm 0.01\end{array}$ & $\begin{array}{l}1.90^{\mathrm{bc}} \\
\pm 0.01\end{array}$ & $\begin{array}{l}1.95^{\mathrm{ab}} \\
\pm 0.04\end{array}$ & * \\
\hline
\end{tabular}

$a, b, c$ Means within the same row with different superscripts are significantly different. Sig. $=$ Significance $* *$ $(P \leq 0.01), *(P \leq 0.05) . N S=$ Non Significant.

Impact of Phytabex plus supplementation (T2: T5) to corn-soybean meal based diets on protein conversion ratio (PCR) and caloric conversion ratio (CCR) are shown in Table (3). Level of Phytabex plus was significantly effective on PCR and CCR during stages of 0-3, 4-5 and 0-5 weeks of age. It is clear that, chicks fed (T1) diets (control group) had better PCR and CCR during all periods, while, chicks fed (T3) diets had worst PCR and CCR values during all periods and theses differences were significant. These findings are in contrast with those obtained by Zhou et al. (2009), who concluded that enzyme preparation containing a mixture of xylanase, protease and amylase enzymes resulted in improvements in ME value when added to broiler corn-soybean diets in starter, grower and finisher phases. Several studies 
had demonstrated some beneficial effect on ME and non-starch polysaccharides digestibility of soybean meal diets, depending on enzyme preparation used (Meng et al., 2005; Awad et al., 2013).

Table (3): Effect of different dietary treatments on protein conversion ratio and caloric conversion ratio.

\begin{tabular}{|c|c|c|c|c|c|c|}
\hline \multirow{2}{*}{ Item } & \multicolumn{6}{|c|}{ Dietary Treatments } \\
\hline & 1 & 2 & 3 & 4 & 5 & Sig. \\
\hline \multicolumn{7}{|c|}{ PCR: Protein conversion ratio (g protein/g gain) } \\
\hline 0-3 weeks & $0.37^{\mathrm{ab}} \pm 0.01$ & $0.37^{\mathrm{ab}} \pm 0.01$ & $0.38^{\mathrm{a}} \pm 0.01$ & $0.36^{\mathrm{b}} \pm 0.01$ & $0.37^{\mathrm{ab}} \pm 0.01$ & $*$ \\
\hline 4-5 weeks & $0.43^{\mathrm{b}} \pm 0.01$ & $0.47^{\mathrm{a}} \pm 0.01$ & $0.49^{\mathrm{a}} \pm 0.01$ & $0.46^{\mathrm{ab}} \pm 0.01$ & $0.47^{\mathrm{a}} \pm 0.02$ & $*$ \\
\hline $0-5$ weeks & $0.40^{\mathrm{c}} \pm 0.01$ & $0.42^{\mathrm{ab}} \pm 0.01$ & $0.43^{\mathrm{a}} \pm 0.01$ & $0.41^{\mathrm{bc}} \pm 0.01$ & $0.43^{\mathrm{ab}} \pm 0.01$ & $* *$ \\
\hline \multicolumn{7}{|c|}{ CCR: Calorie conversion ratio (1000 Kcal/ g gain) } \\
\hline $0-3$ weeks & $49.09^{\mathrm{ab}} \pm 0.19$ & $48.83^{\mathrm{ab}} \pm 0.71$ & $49.47^{\mathrm{a}} \pm 0.14$ & $47.90^{\mathrm{b}} \pm 0.35$ & $49.42^{\mathrm{a}} \pm 0.39$ & $*$ \\
\hline 4-5 weeks & $65.24^{\mathrm{b}} \pm 0.60$ & $71.62^{\mathrm{a}} \pm 2.36$ & $74.59^{a} \pm 0.52$ & $70.00^{\mathrm{ab}} \pm 0.60$ & $72.12^{\mathrm{a}} \pm 3.06$ & $*$ \\
\hline $0-5$ weeks & $57.17^{c} \pm 0.21$ & $60.22^{\mathrm{ab}} \pm 0.82$ & $62.03^{\mathrm{a}} \pm 0.33$ & $58.95^{\mathrm{bc}} \pm 0.47$ & $60.77^{\mathrm{ab}} \pm 1.72$ & $*$ \\
\hline
\end{tabular}

\section{Carcass characteristics}

Table (4) shows the effect of Phytabex plus supplementation on carcass characteristics for chicks slaughtered at 5 wks of age. Dressing, ready to cook and gizzard percentages were significantly affected.

Table (4): Effect of different dietary treatments on carcass characteristics.

\begin{tabular}{|c|c|c|c|c|c|c|}
\hline \multirow{2}{*}{$\begin{array}{l}\text { Item } \\
\text { Carcass } \\
\text { Characteristics } \\
\end{array}$} & \multicolumn{6}{|c|}{ Dietary Treatments } \\
\hline & 1 & 2 & 3 & 4 & 5 & Sig. \\
\hline $\begin{array}{l}\text { Live Body } \\
\text { weight }(\mathrm{g})\end{array}$ & $\begin{array}{c}1486.67 \\
\pm 20.48\end{array}$ & $\begin{array}{c}1499.33 \\
\pm 14.44\end{array}$ & $\begin{array}{c}1438.33 \\
\pm 37.23\end{array}$ & $\begin{array}{c}1571.67 \\
\pm 80.06\end{array}$ & $\begin{array}{c}1573.33 \\
\pm 39.40\end{array}$ & NS \\
\hline $\begin{array}{l}\text { Carcass } \\
\text { weight }(\mathrm{g})\end{array}$ & $\begin{array}{c}1051.33 \\
\pm 12.97\end{array}$ & $\begin{array}{c}1038.00 \\
\pm 5.77\end{array}$ & $\begin{array}{c}1035.67 \\
\pm 20.57\end{array}$ & $\begin{array}{c}1095.67 \\
\pm 82.19\end{array}$ & $\begin{array}{c}1126.00 \\
\pm 32.86\end{array}$ & NS \\
\hline Dressing \% & $70.72^{\mathrm{abc}} \pm 0.62$ & $69.23^{c} \pm 0.56$ & $72.01^{\mathrm{a}} \pm 0.89$ & $69.65^{\mathrm{bc}} \pm 0.41$ & $71.53^{\mathrm{ab}} \pm 0.57$ & $*$ \\
\hline $\begin{array}{l}\text { Abdominal } \\
\text { Fat } \%\end{array}$ & $\begin{array}{c}0.88 \\
\pm 0.26\end{array}$ & $\begin{array}{c}1.14 \\
\pm 0.17\end{array}$ & $\begin{array}{c}1.40 \\
\pm 0.38\end{array}$ & $\begin{array}{c}1.13 \\
\pm 0.25\end{array}$ & $\begin{array}{c}1.44 \\
\pm 0.05\end{array}$ & NS \\
\hline Liver \% & $2.14 \pm 0.11$ & $2.33 \pm 0.13$ & $2.49 \pm 0.07$ & $2.29 \pm 0.17$ & $2.02 \pm 0.21$ & NS \\
\hline Gizzard \% & $1.74^{\mathrm{a}} \pm 0.13$ & $1.31^{\mathrm{b}} \pm 0.10$ & $1.27^{\mathrm{b}} \pm 0.07$ & $1.49^{\mathrm{ab}} \pm 0.07$ & $1.44^{\mathrm{ab}} \pm 0.07$ & $*$ \\
\hline Heart \% & $0.43 \pm 0.04$ & $0.44 \pm 0.03$ & $0.49 \pm 0.01$ & $0.47 \pm 0.05$ & $0.52 \pm 0.07$ & NS \\
\hline Giblets \%* & $4.32 \pm 0.21$ & $4.09 \pm 0.11$ & $4.25 \pm 0.01$ & $4.25 \pm 0.15$ & $3.99 \pm 0.25$ & NS \\
\hline $\begin{array}{l}\text { Ready to } \\
\text { Cook \% \# }\end{array}$ & $\begin{array}{l}75.04^{\mathrm{ab}} \\
\pm 0.63\end{array}$ & $\begin{array}{l}73.33^{\mathrm{b}} \\
\pm 0.67\end{array}$ & $\begin{array}{l}76.26^{\mathrm{a}} \\
\pm 0.88\end{array}$ & $\begin{array}{l}73.91^{\mathrm{b}} \\
\pm 0.42\end{array}$ & $\begin{array}{c}75.52^{\mathrm{ab}} \\
\pm 0.76\end{array}$ & $*$ \\
\hline \multicolumn{7}{|c|}{ Lymphoid Organs \% } \\
\hline Spleen \% & $0.12 \pm 0.01$ & $0.10 \pm 0.02$ & $0.09 \pm 0.02$ & $0.10 \pm 0.02$ & $0.11 \pm 0.02$ & NS \\
\hline Thymus \% & $0.23 \pm 0.04$ & $0.27 \pm 0.02$ & $0.15 \pm 0.05$ & $0.12 \pm 0.05$ & $0.20 \pm 0.07$ & NS \\
\hline Bursa $\%$ & $0.13 \pm 0.05$ & $0.07 \pm 0.01$ & $0.12 \pm 0.03$ & $0.07 \pm 0.01$ & $0.11 \pm 0.03$ & NS \\
\hline
\end{tabular}

The corresponding values of dressing percentages ranged between $69.23 \%$ (T2) and $72.01 \%$ (T3), while ready to cook percentages ranged between $73.32 \%$ (T2) and $76.26 \%$ (T3), while gizzard percentages ranged between $1.27 \%$ (T3) and $1.74 \%$ (T1). Conversely, no significant effects were observed for relative 
weights of other internal organs (liver, heart, spleen, thymus and bursa) in response to dietary treatments. That means no adverse effects noticed on birds fed different levels of enzyme. Although abdominal fat parameter had no significant differences among all treatment groups, different levels of Phytabex plus (T2: T5) had higher values compared to control group (1.14, 1.40, 1.13, 1.44 and 0.88) respectively. These results were similar to those of Jamroz et al. (1996) and Wang et al. (2005) who observed that exogenous dietary enzyme supplementation significantly increased meat yield of broiler. In contrary, Saleh et al. (2005) and Zakaria et al. (2010) reported that dressing percent, heart, gizzard and abdominal fat were not significantly affected due to dietary enzyme supplementation.

\section{Blood parameters}

Table (5) shows the effect of Phytabex plus supplementation in broiler diets on some metabolic functions. The data revealed that chicks fed (T2: T5) diets recorded higher values of total protein (TP) and globulin $(\mathrm{G})$ and lower albumin/ globulin $(\mathrm{A} / \mathrm{G})$ ratio, and these values were significantly different. Change in plasma TP and $\mathrm{G}$ as affected by dietary treatments might be due to role of enzymes in improving digestibility of protein, fiber and organic matter (Table, 5). These effects were significant on albumin level which was decreased with (T2) group in comparison to control (T1). However, it is known that plasma albumin is a very strong predictor of bird's health. On the other hand, plasma globulin is an indicator of immune response and source of gamma globulins (antibodies). Plasma globulin was significantly increased by adding Phytabex plus to chick's diets. Although there are significant differences among treatments in A/G ratio values, and groups (T2: T5) recorded better ratios compared to control (T1) and that means that dietary treatments have improved immunity of chicks. Shehab et al.

Table (5): Effect of different dietary treatments on some blood plasma parameters, 35 days.

\begin{tabular}{|c|c|c|c|c|c|c|}
\hline \multirow[t]{2}{*}{ Item } & \multicolumn{6}{|c|}{ Dietary Treatments } \\
\hline & 1 & 2 & 3 & 4 & 5 & Sig \\
\hline \multirow{2}{*}{ Total Protein (g/ dl) } & $5.84^{\mathrm{b}}$ & $6.14^{\mathrm{ab}}$ & $6.70^{\mathrm{ab}}$ & $7.51^{\mathrm{a}}$ & $6.84^{\mathrm{ab}}$ & \\
\hline & \pm 0.33 & \pm 0.64 & \pm 0.13 & \pm 0.76 & \pm 0.21 & \\
\hline \multirow{2}{*}{ Albumin (g/ dl) } & $4.30^{\mathrm{a}}$ & $3.66^{\mathrm{b}}$ & $4.20^{\mathrm{a}}$ & $4.22^{\mathrm{a}}$ & $4.33^{\mathrm{a}}$ & \\
\hline & \pm 0.15 & \pm 0.06 & \pm 0.06 & \pm 0.14 & \pm 0.12 & \\
\hline \multirow{2}{*}{ Globulin (g/ dl) } & $1.54^{\mathrm{b}}$ & $2.47^{\mathrm{ab}}$ & $2.50^{\mathrm{ab}}$ & $3.29^{\mathrm{a}}$ & $2.50^{\mathrm{ab}}$ & \\
\hline & \pm 0.18 & \pm 0.58 & \pm 0.07 & \pm 0.62 & \pm 0.08 & \\
\hline \multirow{2}{*}{$\mathrm{A} / \mathrm{G}$ ratio \# } & $2.85^{\mathrm{a}}$ & $1.66^{\mathrm{b}}$ & $1.68^{\mathrm{b}}$ & $1.36^{\mathrm{b}}$ & $1.73^{\mathrm{b}}$ & \\
\hline & \pm 0.24 & \pm 0.39 & \pm 0.02 & \pm 0.22 & \pm 0.01 & \\
\hline \multirow{2}{*}{ Cholesterol (mg/ dl) } & 196.50 & 201.00 & 197.50 & 212.00 & 188.50 & \multirow{2}{*}{ NS } \\
\hline & \pm 8.94 & \pm 37.52 & \pm 22.23 & \pm 21.93 & \pm 1.44 & \\
\hline \multirow{2}{*}{ AST (RFU/ dl) } & $31.15^{\mathrm{b}}$ & $24.23^{\mathrm{b}}$ & $32.17^{\mathrm{b}}$ & $57.71^{\mathrm{a}}$ & $31.55^{\mathrm{b}}$ & \\
\hline & \pm 0.25 & \pm 4.05 & \pm 0.47 & \pm 7.60 & \pm 9.93 & \\
\hline \multirow{2}{*}{ ALT (RFU/ dl) } & 46.02 & 42.84 & 52.50 & 38.11 & 53.38 & \multirow{2}{*}{ NS } \\
\hline & \pm 0.72 & \pm 9.33 & \pm 3.42 & \pm 5.36 & \pm 3.59 & \\
\hline
\end{tabular}

$a, b, c$ Means within the same row with different superscripts are significantly different. Sig. $=$ Significance $* *$ $(P \leq 0.01)$, * $(P \leq 0.05) . N S=$ Non Significant.

\# A/ G ratio (Albumin/ Globulin ratio)

(2012) reported that blood serum total protein and liver enzymes (AST) of quails were not significantly affected by feeding dietary Kemzyme. Liver function of broiler chicks as determined by AST and ALT activities was not affected significantly by adding Phytabex plus, except for (T4) with AST. Both AST and ALT showed changes and opposite trends with (T4) diet, where AST significantly increased (31.15 vs. $57.71 \mathrm{RFU} / \mathrm{dl}$ ) and ALT insignificantly decreased (46.02 vs. $38.11 \mathrm{RFU} / \mathrm{dl}$ ) than those fed control (T1) diet. These results are in agreement with those of Abd El-Fattah et al. (2003) and Ibrahim and Saleh (2005). It is well known that values of both AST and ALT are used to detect liver and heart functions (Smith et al. 1998). While, their increase than normal values in blood indicates an impairment in these vital organs. Thus, it can be concluded that using Phytabex plus except for (T4) had no adverse effects on liver functions as confirmed by insignificant alterations in AST and ALT values. Regarding lipid metabolites, results indicated that chicks fed (T2: T5) diets showed insignificant differences in cholesterol concentrations compared with those fed control (T1) diet. Plasma cholesterol ranged between 188.5 and $212.0 \mathrm{mg} / \mathrm{dl}$. Chicks fed (T4) diets gave higher cholesterol figure while, chicks fed (T5) diet recorded lower figure with insignificant differences. These results are disagreement with findings of Elmenawey et al. (2010) who found that Kemzyme did not significantly affect plasma AST concentration. These results 
agreed with those revealed by Sturkie (2000) who reported that the concentration of Avian plasma lipids are influenced by the physical and nutritional status of birds and plasma cholesterol levels of birds are strongly affected by heredity, nutrition, age, sex and environmental conditions. The obtained results are in disagreement with those reported by several investigators (El-Faham and Ibrahim, 2004; Abou El-Wafa et al., 2002; Salem et al., 2008) which concluded that significant increase in plasma total cholesterol was observed when enzyme preparations were added to corn-soybean broilers diets.

\section{Economic efficiency}

Data of economic efficiency carried out during the experimental period are listed in Table (6). Economic efficiency was decreased by 12, 26, 10 and 17\% for broiler chicks fed (T2, T3, T4 and T5 respectively) diets as compared to those fed control (T1) diet. This result might be due to increased feed intake, feed cost and decreased net return. Chicks fed control (T1) diet had the best economic efficiency and relative economic efficiency values being 29.54 and $100 \%$ respectively. Whereas, chicks fed (T3) diet had lower values, being 21.81 and 74\%, respectively. Khattak et al. (2006) reported that, responses to enzymes might be affected by many factors including type and amount cereals in the diet, spectrum and concentration of enzymes used, type and age of animal and type of gut microflora present with physiology of the bird or other possible reasons. The obtained results are in disagreement with those reported by Elnagar (2012) who concluded that enzymes supplementation to broiler diets gave better relative economic efficiency without adverse effects on productive performance or carcass traits of broiler until 6 weeks of age.

Table (6): Effect of different dietary treatments on economic traits.

\begin{tabular}{lccccc}
\hline \multirow{2}{*}{ Economic Traits } & \multicolumn{5}{c}{ Dietary Treatments } \\
\cline { 2 - 6 } & 1 & 2 & 3 & 4 & 5 \\
\hline Average feed intake (Kg) & $2.63 \pm 0.02$ & $2.89 \pm 0.03$ & $2.66 \pm 0.04$ & $2.67 \pm 0.05$ & $2.75 \pm 0.02$ \\
Live body weight (Kg) & $1.46 \pm 0.01$ & $1.52 \pm 0.04$ & $1.38 \pm 0.01$ & $1.45 \pm 0.03$ & $1.45 \pm 0.04$ \\
Feed cost (LE) & $9.66 \pm 0.09$ & $10.72 \pm 0.12$ & $9.81 \pm 0.15$ & $9.86 \pm 0.20$ & $10.14 \pm 0.10$ \\
Total cost (LE) \# & $14.66 \pm 0.09$ & $15.72 \pm 0.21$ & $14.81 \pm 0.15$ & $14.86 \pm 0.20$ & $15.14 \pm 0.10$ \\
Total return (LE)* & $19.72 \pm 0.10$ & $20.56 \pm 0.17$ & $18.64 \pm 0.16$ & $19.55 \pm 0.48$ & $19.57 \pm 0.66$ \\
Net return (LE) & $5.06 \pm 0.56$ & $4.85 \pm 0.03$ & $3.82 \pm 0.01$ & $4.68 \pm 0.27$ & $4.43 \pm 0.55$ \\
Economic efficiency & $34.48 \pm 0.13$ & $30.85 \pm 0.64$ & $25.80 \pm 0.19$ & $31.47 \pm 1.43$ & $29.21 \pm 3.47$ \\
Relative economic & 100.00 & 89.48 & 74.82 & 91.24 & 84.72 \\
efficiency & \pm 0.00 & \pm 1.88 & \pm 0.56 & \pm 4.15 & \pm 10.07 \\
Performance index & $78.52 \pm 0.09$ & $77.95 \pm 0.19$ & $69.31 \pm 0.12$ & $76.18 \pm 2.23$ & $74.35 \pm 4.33$ \\
Production efficiency factor & 179.42 & 163.44 & 191.42 & 168.10 & 199.23 \\
2 & \pm 25.68 & \pm 26.11 & \pm 3.37 & \pm 25.84 & \pm 19.73 \\
\hline
\end{tabular}

\# Total Cost $=($ Feed Cost + price of one-day live chicks + incidental costs $)$;

* According to local price of Kg LBW which was 13.50 L.E.; 1: North (1981); 2: Emmert (2000)

\section{REFERENCES}

Abd El-Fattah, S.A.; Y.M. El-Hommosany and M.F. Ali (2003). Response of quail chicks to diet quantitative immunological and physiological aspects. Egypt. Poult. Sci., 23: 421-440.

Abou El-Wafa, S.; A.R. Osman; A.G. Abdallah and N.A. Hataba (2002). Evaluation of some commercial enzymes in broiler diets based on corn or barley/ soy in combination with growth promoter. Egypt. Poult. Sci., 22: 1023-1045.

Al-Homidan, A.H. (2003). Date waste (whole dates and date pits) as ingredients in broiler diets. Egypt. Poult. Sci., 23: 15-35.

Austin, S.C.; J. Wiseman and A. Chesson. (1999). Influence of non-starch polysaccharides structure on the metabolizable energy of UK wheat fed to poultry. J. Cereal Sci., 29: 77-88. 
Awad, A.L.; A.I.A. Ghonim; M.H.A. Fatouh and M.F. Soliman (2013). Effect of supplementing some growth promoters to duckling diets on growth performance and carcass traits under summer condition. Egypt. Poult. Sci., 33: 371-392.

Barekatain, M.R.; C. Antipatis, M. Choct and P.A. Lji (2013). Interaction between protease and xylanase in broiler chicken diets containing sorghum distillers' dried grains with solubles. Anim. Feed Sci. Technol., 182: 71-81.

Bedford, M.R. (2002). The role of carbohydrates in feedstuff digestion. Pages 319-336 in Poultry Feedstuffs: Supply, Composition and Nutritive Value. J. MacNab and N. Boorman, Ed. CABI, Wallingford, UK.

Cheeke, P.R. (1991). Applied Animal Nutrition: Feeds and Feeding. MacMillan Publishing Co., New York, USA.

Doumas, B., W. Watson and H. Biggs (1971). Albumin standards and the measurement of serum albumin with bromcresol green. Clin. Chem. Acta, 31: 87-96.

Duncan, D.B. (1955). Multiple range and multiple F tests. Biometrics, 11: 1-42.

El-Faham, A.I. and M.T. Ibrahim (2004). Effect of enzyme supplementation on performance, meat quality and economic evaluation of broiler chicks fed low protein diet. Annals Agric. Sci. Moshtohor, 42: 1009-1026.

El-Faham, A.I. and S.A. Ibrahim (2003). Enzyme preparation in broiler diets based on barley. Egypt. J. Nutr. Feeds 6 (special Issue): 87-96.

Elmenawey, M.A.; A.H.R. Ali; M.A.A. Galal and F.K.R. Stino (2010). Influence of enzyme supplementation in the diet on egg production, egg quality and some blood constituents of matrouh hens. Egypt. Poult. Sci., 30: 661-678.

Elnagar, S.H.M. (2012). Impact of enzyme mixture, probiotic or both on performance of broilers fed sorghum based diets. Egypt. J. Nutr. Feeds, 15(1): 123-131.

Emmert, J. (2000). Efficiency of phase feeding in broilers. Proceeding, California Animal Nutrition Conference. Fresno California, USA.

Gornall, A.C.; C.J. Bardawill and M.M. David (1949). Determination of serum proteins by means of Biuret reaction. J. Biol. Chem., 177: 751-766.

Gracia, M.I.; M.J. Aranibar; R. Lázaro; P. Medel and G.G. Mateos (2003). Alpha-amylase supplementation of broiler diets based on corn. Poult. Sci., 82: 436-442.

Greenwood, M.W.; C.A. Fritts and P.W. Waldroup (2002). Utilization of avizyme 1502 in corn-soybean meal diets with and without antibiotics. Poult. Sci., 81 (Suppl. 1): 25 (Abstr.).

Hassanein, H.H.M. (2011). Growth performance and carcass yield of broilers as affected by stocking density and enzymatic growth promoters. Asian J. Poult. Sci., 5: 94-101.

Ibrahim, K.A. and E.S. Saleh (2005). Response of male chicks to skip a day feeding programs. Egypt. Poult. Sci. 25: 351-370.

Jamroz, D.; J. Skorupinska; J. Orda; A. Wiliczkie-wicz and L. Volker (1996). The effect of increased Roxazyme-G supplementation in the broiler fed with triticale rich mixture. Archiv für Geflügelkunde, 60: 165-173.

Kalmendal, R. and R. Tauson (2012). Effects of a xylanase and protease, individually or in combination, and an ionophore coccidiostat on performance, nutrient utilization and intestinal morphology in broiler chickens fed a wheat-soybean meal-based diet. Poult. Sci., 91: 1387-1393.

Khan, S.H.; R. Sardar and B. Siddique (2006). Influence of enzymes on performance of broilers fed sunflower-corn based diets. Pakistan Vet. J., 26: 109-114.

Khattak, F.M.; T.N. Pasha; Z. Hayat and A. Mahmud (2006). Enzymes in Poultry nutrition. J. Anim. Pl. Sci. 16: 1-7.

Kocher, A., M. Choct; M.D. Porter and J. Broz (2002). Effects of feed enzymes on nutritive value of soybean meal fed to broilers. Br. Poult. Sci., 43: 54-63. 
Kocher, A.; M. Choct; G. Ross; J. Broz and T.K. Chung (2003). Effects of enzyme combinations on AME of corn-SBM based diet in broilers. J. Appl. Poult. Res., 12: 275-283.

Lázaro, R.; M. García; M.J. Araníbar and G.G. Mateos (2003). Effect of enzyme addition to wheat-, barley- and rye-based diets on nutrient digestibility and performance of laying hens. Br. Poult. Sci., 44: $256-265$.

Meng, X.; B.A. Slominski; C.A. Nyachoti; L.D. Campbell and W. Guenter (2005). Degradation of cell wall polysaccharides by combinations of carbohyrdrase enzymes and their effect on nutrient utilization and broiler chicken performance. Poult. Sci., 84: 37-47.

Naqvi, L.U. and Nadeem (2004). Bioavailability of metabolizable energy through kemzyme supplementation in broiler rations. Pakistan Vet. J., 24: 98-100.

North, M.O. (1981). Commercial Chicken Production Mannual, 2nd Ed., Av., Publishing Company Inc., WestPort. Connecticut, USA.

NRC (1994). Nutrient Requirements of Poultry. 9th Rev. Ed. Acad. Press, Washington, DC, USA.

Olukosi, O.A.; A.J. Cowieson and O. Adeola (2007). Age-related influence of a cocktail of xylanase, amylase, and protease or phytase individually or in combination in broilers. Poult. Sci., 86: 77-86.

Onu, P.N.; F.N. Madubuike; D.O. Onu and B.U. Ekenyem (2011). Performance and economic analysis of broiler starter chicks fed enzyme supplemented sheep manure-based diets. J. Agric. Biol. Sci., 6: 1419.

Osman, A.M.A.; M.A.H. Soliman; H.H. Hasanein and A.A.A. Abd El-Warth (2007). Evaluation of the growth fed on plant diets supplemented with some feed additives. J. Agric. Sci., Mansoura Univ., 32: 133-150.

Pourreza, J.; A.H. Samie and E. Rowghani (2007). Effect of supplemental enzyme on nutrient digestibility and performance of broiler chicks fed on diets containing triticale. Int. J. Poult. Sci., 6: 115-117.

Reitman, S. and S. Frankel (1957). Determination of serum glutamate oxaloacetate and glutamate pyruvate transaminases. Amer. J. Clin. Path., 28: 56-60.

Richmond, W. (1973). Determination of cholesterol in blood plasma by enzymatic colorimetric method. Clin. Chem., 19: 1350-1356.

Safaa, H.M. (2013). Influence of dietary enzymes prepared at ensiling (ZADO®) from hatch to 42 days of age on productivity, slaughter traits and blood constituents in broiler chickens. Int. J. Poult. Sci., 12: 529-537.

Saleh, F.; M. Tahir; A. Ohtsuka and K. Hayashi (2005). A mixture of pure cellulase, hemicellulase and pectinase improves broiler performance. Br. Poult. Sci., 46: 602-606.

Salem, A.A.; E.M.M. El Anwer; A.M. Abo-Eita and M.M. Namra (2008). Productive and physiological performance of Golden Montazah male chickens as affected by feed restriction and Avizyme supplementation. Egypt. Poult. Sci., 28: 1137-1164.

SAS Institute (2004). JMP Statistics and Graphics Guide, SAS Institute, Cary, NC. USA.

Shehab, A.E.; K.M. Zahran; N.E. Khedr; T.E. Ahmad and F.A. Esmaeil (2012). Effect of dietary enzyme supplementation on some biochemical and hematological parameters of Japanese quails. J. Anim. Sci. Adv., 2: 734-739.

Shirmohammad, F. and M. Mehri (2011). Effects of dietary supplementation of multi-enzyme complex on the energy utilization in rooster and performance of broiler chicks. Afr. J. Biotecnol., 10: 7541-7547.

Smith, A.F., G.J. Beckett; S.W. Walker and P.W.H. Rae (1998). Lecture Notes on: Clinical Biochemistry. Blackwell Science, Malden, USA.

Sturkie, P.D. (2000). Avian physiology 5th Ed Academic press. San Diego, California, U.S.A.

Wang, Z.R.; S.Y. Qiao; W.Q. Lu and D.F. Li (2005). Effects of enzyme supplementation on performance, nutrient digestibility, gastrointestinal morphology, and volatile fatty acid profiles in the hindgut of broilers fed wheat-based diets. Poult. Sci., 84: 875-881. 


\section{El-Faham et al.}

Youssef, A.W.; H.M.A. Hassan; H.M. Ali and M.A. Mohamed (2011). Performance, abdominal fat and economic efficiency of broilers fed different energy levels supplemented with xylanase and amylase from 14 to 40 days of age. World J. Agric. Sci., 7: 291-297.

Zakaria, H.A.H.; M.A.R Jalall and M.A. Abu Ishmais (2010). The influence of supplemental multienzyme feed additive on the performance, carcass characteristics and meat quality traits of broiler chickens. Int. J. Poult. Sci., 9: 126-133.

Zhou, Y.; Z. Jiang; D. Lu and T. Wang (2009). Improved energy-utilizing efficiency by enzyme preparation supplement in broiler diets with different metabolizable energy levels. Poult. Sci., 88: 316-322.

تأثير إضافة المستحضرات الإنزيمية على الأداء الإنتاجى لبدارى التسمين المغذاة على عليقة (ذرة - كسب فول

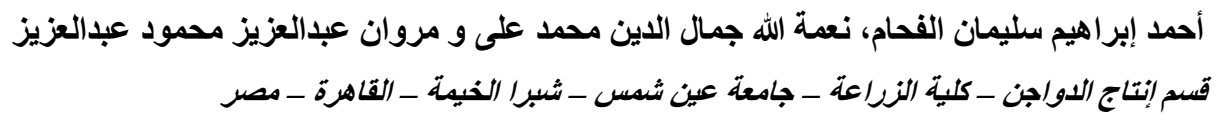

أجريت دراسة للتعرف على تأثير إضافة المستحضر الإنزيمى (Phytabex plus ) إلى عليقة قاعدية (ذرة ـ كسب فول الصويا)

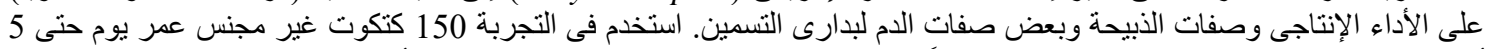

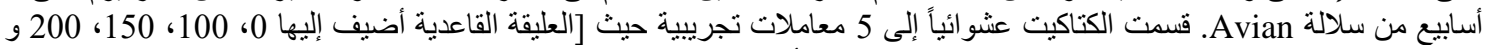
200 جم/ طن Phytabex plus خلال فترة البادئ (صفر - 3 أسبوع) و 0، 100، 150، 200 و 100 جم / طن Phytabex plus خلا فترة النامى (4 - 5 أسبوع)]

كل معاملة غذائية احتوت على 3 مكررات (10 كتكوت بكل بكل مكرر ). أوضحت النتائج أن الكتاكيت المغذاة على عليقة قاعدية مضاف إليها 100 جم /طن Phytabex plus سجلت أعلى وزن حلى على عند عمر 5 أسابيع وذلك بزيادة قدر ها

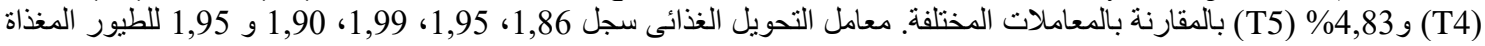

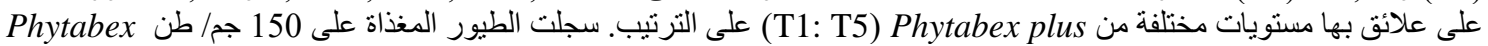
(T3) plus

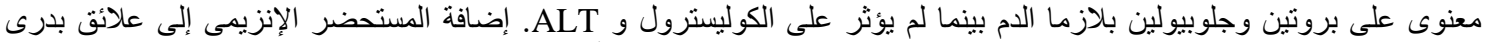

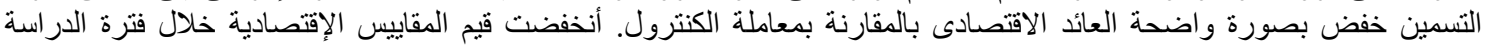

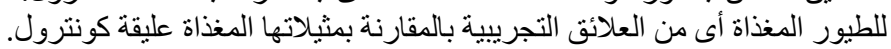

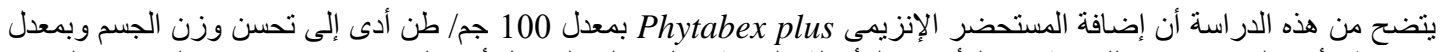

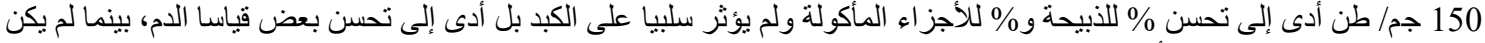
لإضافة المستحضر الإنزيمى ألى عائد اقتصنادى. 